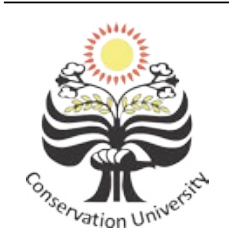

\title{
Kemampuan Berpikir Relasional Siswa dalam Mengerjakan Soal Kontekstual dengan Pendekatan Realistik Pada Topik Fungsi Linear
}

\author{
A. Tatak Handaya Kurniawan', M. Andy Rudhito' \\ 'Program Studi S2 Pendidikan Matematika, PMIPA, FKIP, Universitas Sanata Dharma \\ Email: athk60@gmail.com; rudhito@usd.ac.id \\ DOI: http://dx.doi.org/10.15294/kreano.v7i2.5013
}

Rec eived: February, 2016; Accepted: July, 2016; Published: Dec ember, 2016

\begin{abstract}
Abstrak
Penelitian ini dilatarbelakangi oleh kemampuan berpikir relasional siswa yang masih rendah. Berpikir relasional menjadi salah satu masalah yang menarik dalam pendidikan matematika. Di dalam penelitian ini akan dikaji kemampuan berpikir relasional siswa dalam mengerjakan soal matematika kontekstual pada Pembelajaran Matematika Realistik (PMR). Metode yang digunakan dalam penelitian ini secara deskriptif kualitatif. Penelitian ini dilakukan terhadap siswa kelas VIII SMP Kanisius Sleman dengan topik materi pembelajaran Fungsi Linear. Data proses berpikir relasional siswa diperoleh melalui soal penyelesaian masalah dan analisis penyajian hasil kegiatan siswa. Dari hasil penelitian yang diperoleh menunjukkan bahwa siswa mengalami kesulitan untuk berpikir relasional dalam menghubungkan antara masalah kontekstual dalam PMR terhadap materi fungsi linear terlebih pada penyajian data menggunakan grafik fungsi. Siswa belum mampu menggunakan grafik untuk menentukan hasil fungsi pada permasalahan kontekstual. Saran yang dapat diberikan dari hasil penelitian ini adalah siswa lebih sering diberikan soal yang ng dapat merangsang siswa untuk dapat berpikir relasional, sehingga siswa mampu menyelesaikan masalah kontekstual dengan nalar dan membuat pembelajaran lebih bermakna.
\end{abstract}

\begin{abstract}
This research based on the students' ability in relational thinking which is still low. Thinking relationaly become one of the interesting problems in learning mathematics. This research will discuss students' relational thinking ability in doing contextual mathematics problem in Realistic Mathematics Learning. The method which is used in this research is descriptive qualitative. It is done toward 8th grade students of SMP Kanisius Sleman. The topic is Linear Function. The data of relational thinking is obtained through the students' problem solving on mathematics and the analysis on students' activities result presentation. This research shows that the students got difficulties to think relationaly to correlate contextual problems on learning toward the linear function material prior to data presentation using graph of function. Students are not able to use the graph to the determine the result of function oncontextual problem. From the research, it suggest that students should have been given more problems which stimulate to think relationaly, so that students are able to solve the contextual problem reasonably and make learning more meanigful.
\end{abstract}

Keywords: linear functions; relational thinking; realistic mathematics

\section{PENDAHULUAN}

Dalam melaksanakan proses kegiatan pembelajaran matematika di kelas seringkali guru mengalami erbagai macam kendala. Meskipun seorang guru memiliki gelar tambahan "profesional", yang ditunjukkan melalui sebuah sertifikat profesi, namun banyak guru matematika masih mengalami kesulitan di dalam melaksanakan proses pembelajaran di kelas. Kegiatan belajar mengajar merupakan bagian penting dalam proses belajar yang terjadi dua arah yakni, terjadinya interaksi antara murid dan guru. Meskipun saat ini sudah memasuki jaman globalisasi, dan banyak kajian yang menyatakan guru merupakan seorang fasilitator bagi murid yang sedang belajar, namun kenyataannya bahwa kegiatan belajar mengajar yang terjadi sekarang ini masih cenderung berpusat kepada guru, sehingga guru yang menjadi pusat di dalam kegiatan pem- 
belajaran dan mempunyai peran utama yang sangat mempengaruhi proses belajar siswa. Guru masih cenderung memakai metode pembelajaran secara tradisional (konvensional). Pada pembelajaran tradisional, aktivitas siswa pada umumnya menonton. Guru memberikan contoh soal dan menyelesaikan contoh soal tersebut di papan tulis kemudian meminta siswa mengerjakan sendiri soal dalam buku teks atau Lembar Kerja Siswa (LKS) yang disediakan/ dimiliki siswa. Kegiatan pembelajaran seperti ini akan memiliki dampak pada hasil yang kurang optimal atau dengan kata lain tujuan pembelajaran yang akan dicapai tidak dapat diperoleh dengan maksimal. Kegiatan belajar mengajar semacam ini akan menyebabkan komunikasi yang terjadi hanya searah yaitu dari guru kepada siswa, dan metode yang digunakan biasanya adalah metode ceramah. Dalam memberikan materi, guru hanya mentargetkan agar materi di dalam kurikulum dapat selesai sesuai waktu yang disediakan, sedangkan siswa sebagai subjek yang menerima informasi tidak bisa mengembangkan gagasan/ide yang ada didalam konsep berpikir, melainkan siswa langsung menerima gagasan yang sudah jadi yang diberikan oleh guru. Pengembangan kemampuan berpikir siswa diabaikan, karena didalam melakukan evaluasi pembelajaran guru cenderung lebih menekankan ketercapaian materi yang dapat diserap oleh siswa. Di dalam Permendiknas No 22 Tahun 2006 dinyatakan bahwa pelajaran matematika di sekolah bertujuan agar peserta didik memiliki kemampuan: (a) Menyelesaikan masalah yang meliputi kemampuan memahami masalah, merancang model matematika, menyelesaikan model, dan menafsirkan solusi yang diperoleh dan (b) Memiliki sikap menghargai kegunaan matematika dalam kehidupan, yaitu memiliki rasa ingin tahu, perhatian, dan minat dalam mempelajari matematika, serta sikap ulet dan percaya diri dalam penyelesaian masalah.

Secara garis besar tujuan pelajaran matematika di atas menyatakan betapa pentingnya seorang siswa mendapatkan fasilitas serta berkesempatan mengembangkan kemampuan untuk menyelesaikan masalah selama proses pembelajaran matematika di kelas dan belajar untuk memahami, tidak hanya terampil dalam hal perhitungan. Salah satu cara yeng dapat dilakukan guru untuk mencapai tujuan itu adalah menyusun kegiatan pembelajaran siswa agar siswa dapat menyelesaikan masalah kontekstual dengan mengandalkan kemampuan berpikir relasional.

Pada tingkat sekolah menengah pertama materi aljabar menjadi materi pelajaran yang paling asing di bandingkan materi yang lain, seperti bilangan, geometri, dan statistika. Namun materi Aljabar di tingkat SMP memiliki porsi besar. Dengan materi yang sangat banyak dan guru pada umumnya memberikan materi dengan cara konvensional, maka penekanan materi aljabar sangat lemah. Terlebih siswa merasa bahwa kegunaan aljabar sangat jauh dari kehidupan mereka sehari-hari. Dalam penelitian ini akan dianalisis kemampuan berpikir relasional siswa dalam menyelesaikan soal kontekstual dalam Pembelajaran Matematika Realistik (PMR).

Dari uraian latar belakang di atas, maka dapat dirumuskan masalah: Bagaimanakah kemampuan berpikir relasional siswa dalam menyelesaikan soal kontekstual dalam Pembelajaran Matematika Realistik (PMR)?. Dari rumusan masalah tersebut, maka tujuan dari penelitian ini adalah untuk mengetahui kemampuan berpikir relasional siswa dalam menyelesaikan soal kontekstual dalam Pembelajaran Matematika Realistik (PMR). Manfaat dari penelitian ini adalah guru dapat mengembangkan pembelajaran dengan menggunakan soal kontekstual untuk mengembangkan kemampuan berpikir relasional siswa dalam Pembelajaran matematika Realistik.

\section{Pembelajaran Matematika Realistik}

Salah satu pendekatan pembelajaran matematika yang mengaitkan pengalaman kehidupan nyata siswa dengan materi matematika adalah Realistic Mathematics Education (RME). RME di Indonesia dikenal dengan nama pendidikan matematika realistik dan secara operasional disebut Pembelajaran Matematika Realistik (PMR). PMR merupakan inovasi pembelajaran matematika yang disebut juga inovasi pendekatan pembelajaran matematika yang sejalan dengan teori konstruktivis (Soedjadi, 2006). PMR pertama kali diperkenalkan dan dikembangkan di Belanda 
pada tahun 1970-an oleh Freudenthal. PMR mengacu pada pendapat Freudenthal (1991) yang menyatakan bahwa matematika merupakan aktivitas insani (mathematics as human activity) yang memandang siswa bukan sebagai penerima pasif matematika yang sudah jadi (passive receivers of ready-made mathematics). Namun demikian, siswa harus diberi kesempatan untuk menemukan kembali matematika di bawah bimbingan orang dewasa (Gravemeijer, 1994). De Lange (1996) menggambarkan proses penemuan kembali tersebut harus dikembangkan melalui penjelajahan berbagai persoalan dunia nyata, sehingga matematika harus dekat dengan siswa dan relevan dengan kehidupan nyata sehari-hari. Upaya tersebut dilakukan melalui penjelajahan berbagai situasi dan persoalan-persoalan realistik. Realistik yang dimaksudkan tidak mengacu pada realitas, tetapi pada sesuatu yang dapat dibayangkan oleh siswa (Slettenhaar, 2000).

Dunia nyata adalah segala sesuatu diluar matematika, seperti kehidupan seharihari dan lingkungan sekitar kita (Blum \& Niss, 1989). De Lange (1996) mendefinisikan dunia nyata sebagai suatu dunia nyata yang kongkrit, yang disampaikan kepada siswa melalui aplikasi matematika. Karena itu, pada pembelajaran matematika realistik proses pembelajarannya dialihkan pada situasi dunia nyata. Proses pengembangan ide dan konsep matematika yang dimulai dari dunia nyata inilah yang disebut matematisasi konseptual (de Lange, 1996). Soedjadi (2006) menyatakan bahwa dalam PMR lebih diperhatikan adanya potensi pada diri siswa yang justru harus dikembangkan. Potensi yang ada pada diri siswa akan mempunyài dampak kepada bagaimana tindakan yang harus dilakukan guru dalam mengelola pembelajaran matematika. Selain itu, juga akan berdampak kepada bagaimana siswa membiasakan melakukan kegiatan yang diharapkan muncul sesuai kemampuan diri yang dimilikinya. Keduanya akan berpengaruh kepada budaya guru dalam mengajar dan bagaimana budaya siswa harus belajar Karakteristik pembelajaran matematika realistik (Gravemeijer, 1994; de Lange, 1996), antra lain (a) Menggunakan masalah konteks (the use of context). Pembelajaran diawali dengan menggunakan masalah konteks, tidak dimulai dengan sistem formal. Masalah konteks yang diangkat sebagai topik pembelajaran harus merupakan masalah sederhana yang dikenal siswa; (b) Menggunakan model (the use models, bridging by vertical instruments). Istilah model berkaitan dengan model situasi dan model matematika yang dikembangkan sendiri oleh siswa sebagai jembatan antara level pemahaman yang satu ke level pemahaman yang lain dengan menggunakan instrumeninstrumen vertikal seperti model-model, skema-skema, diagram-diagram, simbol-simbol dan sebagainya; (c) Menggunakan kontribusi siswa (student contribution) Kontribusi yang besar pada proses belajar diharapkan datang dari siswa, artinya semua pikiran (konstruksi dan produksi) siswa diperhatikan; (d) Proses pengajaran yang interaktif (interactivity) Mengoptimalkan proses mengajar-belajar dan terdapat interaksi yang terus menerus antar siswa dengan siswa, siswa dengan guru dan siswa dengan sarana dan prasarana merupakan hal penting dalam pembelajaran matematika realistik, sedemikian hingga setiap siswa mendapatkan manfaat positif dari interaksi tersebut; dan (e) Terintegrasi dengan topik lainnya (intertwining) Matematika merupakan ilmu yang terstruktur, oleh karena itu keterkaitan dan keterintegrasian antar topik (unit pelajaran) harus dieksplorasi untuk mendukung terjadinya proses pembelajaran yang lebih bermakna. sehingga memunculkan pemahaman secara serentak.

\section{Soal Kontekstual}

Berdasarkan tingkat realitasnya De Lange (Sabandar, 2001), membedakan konteks atas tiga jenis yaitu: (a) Tidak ada konteks. Tidak ada konteks masalah nyata, yang ada hanya soal dari topik Matematika, contoh soal: Diketahui $f(x)=4 x-2$, Tentukan nilai dari $f(3)$ ! ; (b) Konteks kamuflase. Dalam konteks ini soal matematika di perbaiki seolah-olah seperti permasalahan sebenarnya. Contoh soal: Harga 2 buku +3 pensil adalah Rp 7000,00. Berapakah harga 1 buah buku jika harga 1 buah pensil $\mathrm{Rp} 1000,00$. (c) Konteks relevan dan esensial. Dalam konteks ini soal-soal betulbetul memiliki konteks yang relevan dengan konsep matematika yang sedang dipelajari. 


\section{Berpikir Relasional}

Berpikir relasional sangat penting dalam matematika, karena ada banyak ide-ide dasar dalam matematika yang mengandung hubungan antara representasi yang berbeda dari angka dan operasi antara angka dan objek matematika lainnya (Molina, Castro, \& Ambrose, 2005). Berpikir relasional memainkan peran sentral dalam kognisi manusia.

Berpikir relasional termasuk kemampuan kita untuk memahami analogi antara objek atau peristiwa yang tampaknya berbeda dan untuk menerapkan aturan abstrak dalam situasi baru (Doumas \& Hummel, 2005). Berpikir relasional menganggap tambahan informasi secara simultan dan mencari pola hubungan identifikasi selanjutnya. Hal ini sering berhubungan dengan intuisi dan karakteristik matematika terapan, dan bidang antar-disiplin.

Oleh karena itu, pemikiran relasional adalah berpikir dengan membangun hubungan berbagai objek / konteks yang terkait satu sama lain. Berpikir relasional hampir sama seperti apa yang dikatakan Skemp (1976) tentang pemahaman relasional, yaitu mengetahui apa yang dikerjakan dan mengapa hal itu dilakukan. Skemp (Anggara, 2010:10) menyatakan pemahaman relasional kemampuan seseorang menggunakan suatu prosedur matematis yang berasal dari hasil menghubungkan berbagai konsep matematis yang relevan dalam menyelesaikan suatu masalah dan mengetahui mengapa prosedur tersebut dapat digunakan (knowing what to do and why). Pemahaman relasional sifat pemakaiannya lebih bermakna, termuat suatu skema atau struktur yang dapat digunakan untuk menyelesaikan masalah yang lebih luas. Siswa yang berusaha memahami secara relasional akan mencoba mengaitkan konsep baru dengan konsep-konsep yang dipahami untuk dikaitkan dan kemudian merefleksi keserupaan dan perbedaan antara konsep baru dengan pemahaman sebelumnya. Pembelajaran untuk mencapai pemahaman relasional tidak hanya sekedar menyampaikan materi sedemikian sehingga siswa bisa mengerjakan persoalanpersoalan secara prosedural. Namun, pembelajaran harus dirancang sedemikian rupa sehingga siswa bisa mencapai pemahaman relasional. Hal ini membutuhkan kreativitas guru untuk merancang pembelajaran yang bisa mencapai sasaran tersebut, sehungga secara psikologis guru harus bekerja lebih keras untuk mencapainya.

\section{METODE PENELITIAN}

Penelitian ini menggunakan pendekatan kualitatif. Pendekatan ini digunakan untuk mengungkap atau memperoleh gambaran tentang permasalahan yang dihadapi oleh siswa dalam dalam berpikir relasional untuk menyelesaikan soal kontekstual, peneliti berusaha melakukan pemeriksaan secara teliti dan hatihati serta secara detail dan mendalam terhadap subyek atau siswa mengenai apa yang dilakukan, diucapkan, dan yang dipikirkan siswa pada saat menghadapi dan menyelesaikan soal cerita.

Penelitian dilakukan dengan mengobservasi pembelajaran matematika yang berlangsung pada pembelajaran matematika. Data-data lain diperoleh dari wawancara dengan guru mata pelajaran dan studi dokumentasi yang berkaitan dengan pembelajaran matematika.

Analisis data dilakukan dengan: mengorganisir informasi yang diperoleh; membaca keseluruhan informasi dan membuat klasifikasi; membuat uraian terperinci mengenai hal yang kemudian muncul dari hasil pengujian; menetapkan pola dan mencari hubungan antara beberapa kategori; melakukan interpretasi; dan menyajikan secara naratif. Subyek dari penelitian ini adalah Siswa Kelas VIIIA SMP Kanisius Sleman tahun Pelajaran 2015/2016 sebanyak 20 anak yang dibagi dalam kelompok yang beranggotakan 4 orang serta satu orang siswa yang dianggap sebagai siswa yang paling unggul di kelas tersebut $\mathrm{Di}$ dalam kelompok siswa diminta untuk mendiskusikan soal kontekstual. Dalam proses kegiatan pembelajaran dengan diskusi ini akan diambil data mengenai karakterisik PMR. Dari proses diskusi akan diamati karakteristik PMR akan muncul atau tidak. Sedangkan seorang siswa yang unggul diminta untuk menjelaskan hasil dikusi kelompok. Dipilih siswa yang unggul dengan maksud telah diasumsikan terlebih dahulu bahwa siswa akan kesulitan menyelesaikan soal kontekstual yang disebabkan kemampuan berpikir relasional sis- 
wa masih rendah, sehingga jika siswa yang unggul kesulitan untuk menyelesaikan soal kontekstual, maka siswa yang lain juga akan mengalami kesulitan yang lebih. Data untuk pemilihan siswa tersebut diperoleh dari keterangan guru.

Para siswa diberikan soal kontekstual lalu diminta untuk mengerjakan secara berkelompok. Adapun soal yang diberikan peneliti dapat dilihat pada Tabel 1.
Hipotesis ( dugaan sementara) dari jawaban soal kontekstual diatas adalah: belum mendapatkan materi terkait grafik fungsi. Kemudian setelah siswa mendapatkan grafik fungsi, siswa diharapkan dapat menghubungkan grafik fungsi untuk menyelesaikan masalah selanjutnya, sehingga diperoleh dugaan bahwa siswa menggunakan kemampuan berpikir relasionalnya untuk menyelesaikan masalah yang diberikan.

Tabel 1. Soal Kontekstual

Sebuah lokasi penambangan pasir menetapkan harga pasir setiap truk sebesar Rp 200.000. Untuk setiap perusahaan pasir yang datang dikenakan biaya tambahan Rp 500.000 untuk seberapa pun banyak truk yang dibawa dalam satu hari. Pada suatu hari CV Barokah mengirim 4 truk dan CV Sentosa mengirim 7 truk.

a. Berapakah biaya yang harus dikeluarkan masing-masing oleh CV Barokah dan CV Sentosa?

b. Buatlah grafik dari persoalan diatas!

c. Jika CV Gemilang mengirim 12 truk, berapakah biaya yang harus dikeluarkan?

d. Berapa banyak truk yang dapat dikirimkan CV Handaya dengan uang sebesar Rp. 2.750.000.

Tabel 2. Dugaan jawaban siswa untuk soal kontekstual

\begin{tabular}{ll}
\hline Diketahui & $:$ \\
harga pasir & : Rp. 200.000,00/ truk \\
biaya tambahan & : Rp 500.000,00/perusahaan \\
CV Barokah & : mengirim 4 truk \\
CV Sentosa & : mengirim 7 truk
\end{tabular}

Ditanyakan:

a. Biaya yang harus dikeluarkan oleh masing-masing CV Barokah dan CV Sentosa

b. Grafik dari a)

c. Biaya yang harus dikeluarkan CV Gemilang jika mengeluarkan 12 truk

d. Banyak truk yang dikirim, Jika CV Handaya membawa uang Rp 2.750.000,00 Jawab:

$\begin{array}{ll}\text { a. CV Barokah } & : 4 \times \operatorname{Rp} 200.000+\operatorname{Rp} 500.000=\operatorname{Rp} 1.300 .000 \\ \text { CV Sentosa } & : 7 \times R p 200.000+\operatorname{Rp} 500.000=\operatorname{Rp} 1.900 .000\end{array}$

b.

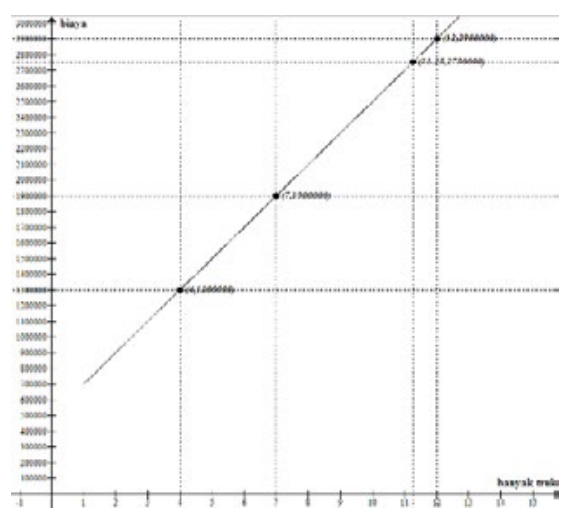

Gambar 1. Grafik penyelesaian soal b)

c. Melalui grafik diperoleh informasi bahwa jika CV Gemilang mengirim 12 truk maka akan membayar Rp 2.900.000

d. Melalui grafik diperoleh informasi bahwa jika CV Handaya membawa uang Rp 2.750.000,00 maka dapat mengirimkan 11,25 truk. Namun karena truk merupakan benda konkret yang tidak dapat berupa pecahan, maka jumlah truk yang dapat dikirim adalah 11 truk. 
Di dalam dugaan jawaban siswa terhadap soal kontekstual pada topik fungsi linear siswa diarahkan dan diharapkan dapat membuat grafik fungsi linear dengan keterangan bahwa siswa

\section{HASIL DAN PEMBAHASAN}

\section{Pelaksanaan Pembelajaran}

Pembelajaran dilekasanakan pada hari Selasa, 13 Oktober $2015 \mathrm{jam}$ 07.40 - 08.20 WIB di kelas 8 A SMP Kanisius Sleman. Metode pembelaran adalah dengan diskusi kelompok, dengan jumlah siswa 20 anak dengan anggota pada masing-masing kelompok 4 orang, sehingga terbentuk 5 kelompok.

Berdasarkan tabel di atas, pelaksanaan pembelajaran di kelas yang telah dilakukan sudah memenuhi karakteristik dari pembela- jaran yang mengggunakan Pendekatan Matematika Realistik. Hal ini dapat dilihat permasalahan kontekstual yang dihadapi siswa serta aktivitas atau kegiatan yang dilakukan oleh siswa dan guru pada saat pembelajaran berlangsung. Siswa aktif berdiskusi dalam kelompok yang bermakna bahwa siswa berkontribusi aktif dalam pembelajaran. hanya sebagai fasilitator, dimana guru hanya menuntun siswa dalam menyelesaikan soal yang kurang dimengerti oleh siswa.

\section{Hasil Deskripsi pekerjaan siswa}

Berikut disajikan hasil diskusi salah satu kelompok dimana seorang siswa yang akan menjadi subjek wawancara menjadi anggota kelompok tersebut. Hasil kelompok ini merupakan jawaban terbaik dari kelompok yang lain.

Tabel 3. Kegiatan Pembelajan Matematika Realistik

\begin{tabular}{|c|c|}
\hline Kegiatan Pembelajaran & Keterangan \\
\hline \multicolumn{2}{|l|}{ Pendahuluan } \\
\hline \multicolumn{2}{|l|}{$\begin{array}{l}\text { 1. Guru mengkondisikan siswa untuk belajar. Siswa dibagi keda- } \\
\text { lam kelompok ( } 4 \text { orang) }\end{array}$} \\
\hline \multicolumn{2}{|l|}{ 2. Guru memotivasi siswa untuk belajar } \\
\hline \multicolumn{2}{|l|}{ 3. Melakukan apersepsi } \\
\hline \multicolumn{2}{|l|}{ 4. Guru menyampaikan tujsn dan rencana pembelajaran } \\
\hline \multicolumn{2}{|l|}{ Kegiatan Inti } \\
\hline $\begin{array}{l}\text { Guru memulai kegiatan dengan mengajukan masalah konteks- } \\
\text { tual dengan sedikit penjelasan. Kemudian siswa diminta untuk } \\
\text { memahami permasalahan. }\end{array}$ & $\begin{array}{c}\text { Karakteristik I } \\
\text { Menggunakan masalah konteks }\end{array}$ \\
\hline $\begin{array}{l}\text { Siswa diberi kesempatan untuk mengajukan pertanyaan jika } \\
\text { mengalami masalah }\end{array}$ & $\begin{array}{c}\text { Karaketeristik IV } \\
\text { Proses pengajaran interaktif }\end{array}$ \\
\hline $\begin{array}{l}\text { Siswa didalam kelompok menyelesaikan masalah kontekstual } \\
\text { secara matematis }\end{array}$ & $\begin{array}{l}\text { Karakteristik II } \\
\text { Menggunakan model }\end{array}$ \\
\hline $\begin{array}{l}\text { Siswa bekerjasama untuk menyelesaikan masalah dengan cara } \\
\text { mereka sendiritampa bantuan dari guru }\end{array}$ & $\begin{array}{l}\text { Karakteristik III } \\
\text { Menggunakan kontribusi siswa }\end{array}$ \\
\hline Jika siswa mengalami kesulitan, guru membimbing seperlunya. & $\begin{array}{c}\text { Karaketeristik IV } \\
\text { Proses pengajaran interaktif }\end{array}$ \\
\hline Siswa diberikan kesempatan untuk menyajikan hasil diskusi & $\begin{array}{l}\text { Karakteristik III } \\
\text { Menggunakan kontribusi siswa }\end{array}$ \\
\hline Membandingkan jawaban antar kelompok & $\begin{array}{c}\text { Karaketeristik IV } \\
\text { Proses pengajaran interaktif } \\
\end{array}$ \\
\hline \multicolumn{2}{|l|}{ Penutup } \\
\hline $\begin{array}{l}\text { Guru mengarahkan dan memberi kesempatan pada siswa untuk m } \\
\text { prosedur terkait dengan masalah kontekstual yang diselesaikan. }\end{array}$ & rik kesimpulan suatu $k$ \\
\hline
\end{tabular}




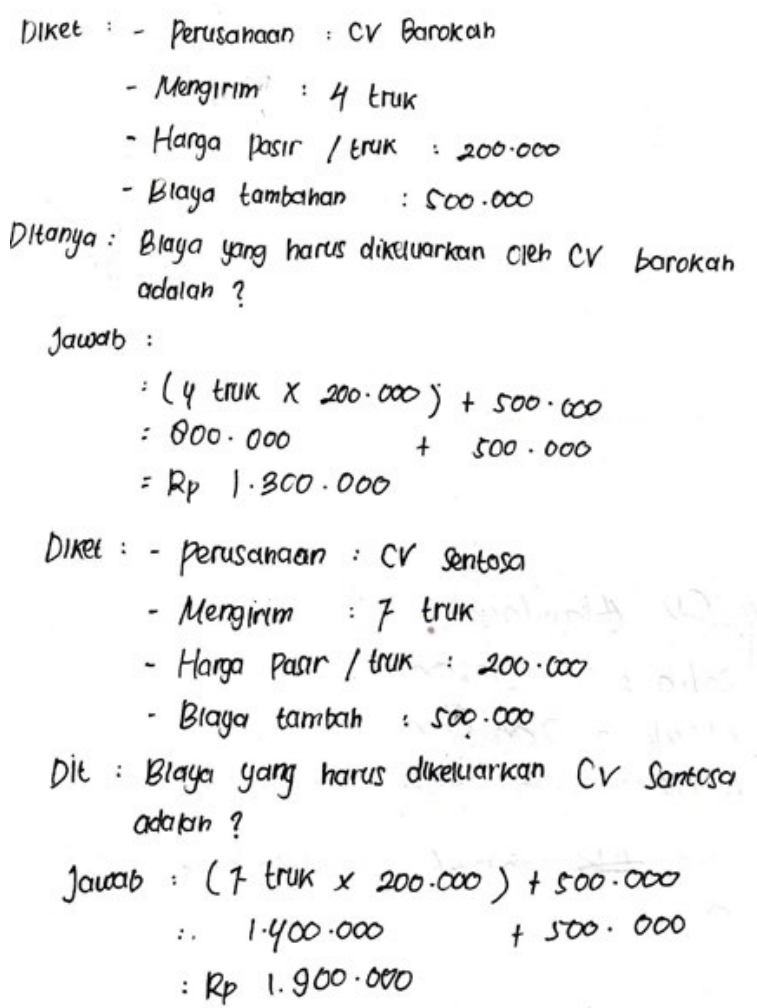

Gambar 2. Hasil diskusi kelompok siswa soal a)

Pada gambar 2. diatas menunjukkan bahwa siswa mampu berpikir relasional dalam memahami analogi antara permasalahan nyata dan menerapkan aturan matematika memecahkan masalah kontekstual. Dari kelima kelompok, 4 kelompok mampu menjawab permasalahan a dengan model yang sama.

Namun ada satu kelompok yang tidak tepat dalam memodelkan permasalahan kontekstual, sebagai berikut:

$$
\begin{aligned}
\text { CV. Barokah } & =(\operatorname{Rp~200.000+Rp~500.000~}) \times 4 \\
& =\operatorname{Rp~} 2.800 .000 \\
\text { CV. Sentosa } & =(\operatorname{Rp~} 200.000+\operatorname{Rp} 500.000) \times 7 \\
& =\operatorname{Rp~} 4.900 .000
\end{aligned}
$$

Dari hasil jawaban kelompok ini maka dapat dilihat bahwa jawaban untuk permasalah berikutnya tidak tepat.

b)

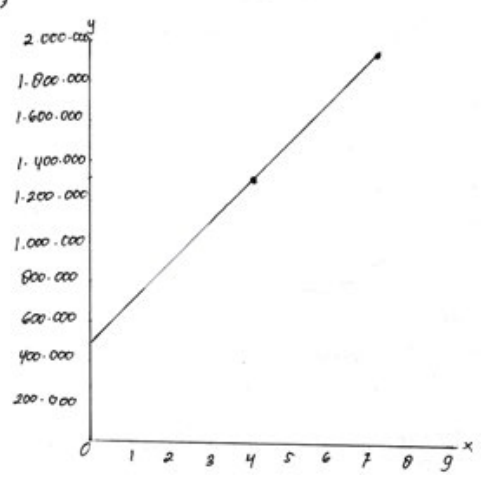

Gambar 3. Hasil diskusi kelompok siswa soal b)

Dari grafik diatas dapat dilihat bahwa siswa mampu membuat garis lurus dengan syarat jika dua titik diketahui. Namun jika dibandingkan dengan asumsi jawaban pada bagian metode penelitian terdapat perbedaan hasil grafik yang diperoleh. Pada grafik asumsi jawaban, grafik berpangkal pada titik koordinat $(1,700000)$, sedangkan jawaban siswa grafik berpangkal pada titik (0, 500000). Siswa beranggapan bahwa jika tidak ada truk yang datang perusahaan tetap membayar Rp 500.000.

Pada gambar 4. Siswa menyelesaikan dengan cara memodelkan seperti halnya per-

$$
\begin{aligned}
& \text { Ditet:- Perusahaan : CV Gerilang } \\
& \text { - mengirim = } 12 \text { truk } \\
& \text { - harga pasir / truk }=200.000 \\
& \text { - braya tambahan }=500000 \\
& \text { Ditanga = Biaya yg di teluartan? } \\
& J \omega b=(12 \text { trut } \times 200.000)+500.000 \\
& =2400.000+500.000 \\
& =2900 \cdot 000
\end{aligned}
$$

Gambar 4. Hasil diskusi kelompok siswa soal c) 


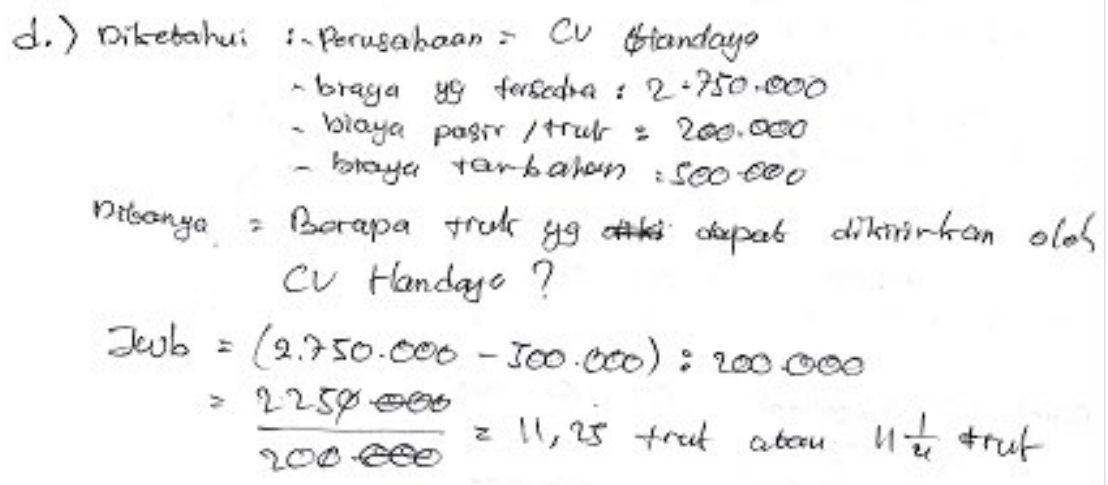

Gambar 5. Hasil diskusi kelompok siswa soal d)

masalahan a. Siswa tidak mampu meyelesaikan seperti asumsi yang diharapkan bahwa jawaban dapat dilihat dari grafik fungsi yang telah dibuat pada gambar 3. Hal ini dikuatkan dengan dengan hasil wawancara siswa yang menyatakan bahwa siswa lebih mudah menjawab seperti penyelesaian soal a. Hal ini memperlihatkan bahwa siswa kurang mampu berpikir relasional siswa kurang mampu memahami analogi antara permasalahan yang tampaknya berbeda namun sebenarnya hampir sama dan siswa tidak mampu menerapkan secara maksimal penggunaan grafik yang telah dibuat untuk menyelesaikan masalah.

Pada gambar 5. Siswa mampu menyelesaikan permasalahan yang berbeda melalui perhitungan, namun dalam mengambil kesimpulan jawaban masih kurang tepat. Hal ini disebabkan karena siswa hanya mengambil jawaban dari perhitungannya tanpa berpikir relasional bahwa truk tidak dapat bernilai seperempat $(0,25)$.

Melalui deskripsi hasil pekerjaan siswa dalam menyelesaikan permasalahan kontekstual pada topik fungsi linear ini sudah terlihat bahwa siswa dapat menerima Pembelajaran Matematika Realistik, namun untuk harapan bahwa siswa dapat berpikir relasionalsiswa masih mengalami kesulitan. Hal ini disebabkan siswa sudah terbiasa dengan soal-soal perhitungan yang konsepnya sudah diberikan oleh guru. Oleh karena itu guru perlu memberikan faslitas kepada siswa berupa soal-soal kontekstual, sehingga siswa mendapatkan pengalaman belajar yang lebih bermakna serta siswa lebih leluasa menggunakan kemampuan berpikir relasional.

\section{SIMPULAN DAN SARAN}

Dari hasil penelitian melalui Pembelajaran Matematika Realistik pada siswa kelas VIII SMP Kanisius Sleman, peneliti dapat mengambil kesimpulan bahwa siswa masih mengalami kesulitan untuk berpikir relasional dalam menyelesaikan soal kontekstual. Hal ini disebabkan karena siswa terbiasa melakukan perhitungan matematika secara prosedural. Sehingga siswa dalam menyelesaikan masalah terpaku pada tata cara yang biasa dilakukan dan menjadi cara yang baku bahwa soal matematika harus diselesaikan dengan penghitungan tertentu. Melalui penelitian ini tampak bahwa siswa kurang mampu berpikir relasional dalam menggunakan grafik fungsi untuk menyelesaikan permasalaahan kontekstual fungsi linear. Siswa merasa lebih mudah menghitung nilai fungsi menggunakan operasi bilangan daripada menggunakan grafik fungsi yang telah didapatkan.

Berdasarkan hasil dari penelitian ini diharapkan dapat dikembangkan penelitian lanjut yang lebih mendalam, terutama dalam pengembangan proses berpikir relasional siswa, terlebih pada materi aljabar, dimana dalam meyelesaikan masalah aljabar siswa sangat terpaku oleh prosedur yang diberikan oleh guru maupun yang sudah tertera didalam buku.

Didalam pembelajaran matematika, siswa sering merasa kesulitan untuk menangkap materi, hal ini diindikasikan karena siswa kurang mendapatkan pembelajaran yang bermakna, oleh karena itu guru diharapkan dapat mengarahkan siswa untuk belajar matematika dengan dihadapkan pada permasalahanpermasalahan kontekstual. Dengan menye- 
lesaikan/ menganalisis masalah kontekstual siswa akan merasa belajar lebih bermakna, karena dengan masalah kontekstual siswa akan dihadapkan pada masalah yang menggambarkan situasi nyata sehari-hari sehingga siswa mempunyai gambaran/ tujuan nyata dalam belajar matematika.

\section{DAFTAR PUSTAKA}

Blum, W., \& Niss, M., (1989). Mathematical Problem Solving, Modelling, Aplications, and Links to Other Subjects - State, Trends and Issues in Mathematics Instruction. Dalam Blum, W. Niss, M. \& Huntley, I., (Eds). Modelling, Aplications and Applied Problem Solving: teaching mathematics in a real contexts. Chichester. Ellis Horwoord.

Depdiknas. (2006). Peraturan Menteri Pendidikan Nasional No.22 (standar isi), 23(standar kompetensi lulusan), dan 24(Pelaksanaan Permen 22 dan 23).

Doumas, L. A. A., \& Hummel, J. E. (2005). Approaches to Modeling Human Mental Representations: What Works, What Doesn't, and Why. In K. J. Holyoak,
\& R. G. Morrison (Eds.), The Cambridge Handbook of Thinking and Reasoning. Cambridge: University press.

De Lange, J. (1987). Mathematics, insight and meaning. Utrecht: OW \&OC

Freudenthal, H. (1991). Revisiting Mathematics Education. China Lectures. Dordrecht: Kluwer Academic Publishers. http://www.fi.ruu.nl/

Gravemeijer, K.P.E. (1994). Developing realistic mathematics education. Utrecht: CD-ß Press / Freudenthal Institute

Molina, M., Castro, E., \& Ambrose, R. (2005). Enriching Arithmetic Learning by Promoting Relational Thinking. The International Journal of Learning, 12(5), 265-270.

Skemp, Richard R. (1989). Relational understanding and instrumental understanding. Department of education, university of warwick

Slettenhaar. (2000). Adapting Realistic Mathematics Education in the Indonesian Context. Majalah IImiah Himpunan Matematika Indonesia (Prosiding Konferensi Nasional Matematika X ITB, 17-20 Juli 2000.

Soedjadi, R. (2006). Dasar-Dasar Pendidikan Matematika Realistik Indonesia. Makalah yang disajikan pada kegiatan workshop di LPMP Surabaya. 